\title{
CONCEPTS OF COLOR, SHAPE, SIZE AND POSITION IN TEN CHILDREN WITH RETT SYNDROME
}

\author{
Renata de Lima Velloso', Ceres Alves de Araújo', José Salomão Schwartzman ${ }^{7}$
}

\begin{abstract}
Individuals with Rett syndrome (RS) present severe motor, language and cognitive deficits, as well as spontaneous hand movement loss. On the other hand, there are strong evidence that these individuals use the eyes with intentional purpose. Ten girls aged $4 y 8 \mathrm{~m}$ to $12 \mathrm{y} 10 \mathrm{~m}$ with RS were assessed with a computer system for visual tracking regarding their ability of indicating with eyes the recognition of concepts of color (red, yellow and blue), shape (circle, square and triangle), size (big and small) and spatial position (over and under) to which they were first exposed to. Results from comparing the time of eyes fixation on required and not required concepts did not differ significantly. Children did not show with eyes the recognition of the required concepts when assessed with eye tracking system.
\end{abstract}

KEY WORDS: Rett syndrome, cognition, eye movement measurements, eye movements.

\section{Conceitos de cor, forma, tamanho e posição em dez crianças com síndrome de Rett}

Resumo - Pessoas com sindrome de Rett (SR) apresentam severos prejuízos psicomotores, verbais, cognitivos e perda das habilidades manuais proposicionais que impedem o conhecimento de suas reais aquisições intelectuais. Entretanto, estudos relatam que essas pessoas utilizam o olhar com finalidade intencional. $O$ objetivo deste estudo foi avaliar se crianças com SR, após terem sido expostas aos conceitos de cor (vermelho, amarelo e azul), forma (círculo, quadrado e triângulo), tamanho (grande e pequeno) e posição espacial (em cima e em baixo), manifestam o reconhecimento desses conceitos com o olhar, avaliado com equipamento computadorizado de rastreamento ocular. Foram avaliadas dez crianças com diagnóstico de SR, com idades entre 4 anos e 8 meses e 12 anos e 10 meses. Os resultados não indicaram diferenças significativas no tempo de fixação do olhar das crianças quando comparados os conceitos solicitados e os não solicitados. Concluiuse que, com o método utilizado, as crianças não reconheceram os conceitos avaliados.

PALAVRAS-CHAVE: síndrome de Rett, cognição, medições dos movimentos oculares, movimentos oculares.

Rett syndrome (RS) is considered a disorder linked to a dominant $\mathrm{X}$ chromosome, lethal in the male gender and for this reason is only studied in females'. Today, it is known that there are some cases where men can be affected: boys having Klinefelter syndrome comorbidity, boys presenting severe encephalopathy, and brothers having affected sisters who were born with severe neurological disorders, generally evolving into premature death ${ }^{1-3}$. In 1999, Amir et al. ${ }^{4}$ described mutations of the MECP2 gene in patients with RS, classifying it as a genetic alteration, in fact linked to a dominant $X$ chromosome. The $M E C P 2$ gene codifies the MeCP2 protein which operates as a global transcribing repressor and acts in different locations. The different mutations that have already been identified can be responsible for the various phenol-typical patterns observed ${ }^{5}$.
RS is a condition that evolves with progressive acquisition loss of psychomotor development (motor and cognitive acquisitions), deceleration of cranial perimeter growth and verbal communication inability. Nevertheless, spontaneous stereotypical hand movement is strongly suggestive of this syndrome, with loss of voluntary hand functions, once acquired. These people tend to lock their hands and hold them in front along the central part of the body displaying the stereotypical movement of "washing their hands", rocking the hands in front of the face, putting them in the mouth and, occasionally, even biting them ${ }^{6}$. According to the Diagnostic and Statistical Manual of Mental Disorders - DSM-IV ${ }^{7}$, RS is classified as an pervasive developmental disorder, for which incidence is estimated at 1:15.000 girls. There is little research and little documented information about the cognitive potential

\footnotetext{
'Universidade Presbiteriana Mackenzie, Programa de Pós-Graduação em Distúrbios do Desenvolvimento, São Paulo SP, Brasil; ${ }^{2}$ Pontifícia Universidade Católica de São Paulo, Programa de Pós-Graduação em Psicologia Clínica, São Paulo SP, Brasil. Financial support: CAPES and MackPesquisa (Universidade Presbiteriana Mackenzie).
}

Received 16 June 2008, received in final form 13 October 2008. Accepted 8 November 2008.

Dra. Renata de Lima Velloso - Rua da Consolação 930 / Edifício Amantino Vassão / Térreo / Laboratório Interdisciplinar de Distúrbios do Desenvolvimento - 01302-907 São Paulo SP - Brasil.E-mail: relimavelloso@yahoo.com.br 
of people with RS. Most of the studies are in agreement that, before the onset of the regression and the diagnosis, they follow typical developmental phases, even though, when seen retrospectively, these phases can be considered incomplete or delayed ${ }^{8}$. The evaluation of cognitive functions almost always depends on verbal or gesture responses, and the motor and communication impairment specific to RS impede the evaluation of cognitive skills in this population, which provokes the researcher to reflect about other strategies of evaluation. Baptista ${ }^{9}$ and Amorosino ${ }^{10}$ used a computerized ocular tracking system to demonstrate that girls with RS truly seemed to have an intentional look, objectively corroborating many qualitative reports that these girls use their eyes with intentional purpose. The fixed and intense stare as a form of communication or as an expression of desire, allows it to be used as a means of evaluating cognitive aspects ${ }^{8,1,12}$.

The objective of this study was to evaluate recognition of concepts of color (red, yellow and blue), shape (circle, square and triangle), size (big and small) and spatial position (over and under) in 10 children with RS, using the computerized ocular tracking equipment.

\section{METHOD}

Ten girls clinically diagnosed with RS (clinical stage III or IV), aged between 4 years 8 months and 12 years 10 months, having different schooling levels participated in this study (Table). All of the children were submitted to a genetic examination for mutations of the MECP2 gene; 8 of them tested positive and 2 received negative results, suggesting that the exam be reapplied.

The severity of the girls' clinical condition was characterized by applying the Kerr et al. ${ }^{13}$ standardized scale. This scale is composed of 20 items with scoring of 0,1 or 2 . The maximum score on the scale is 40 points. The greater the score obtained by the girl, the more severe her RS condition. The total scores for each child can be found in Table. The scale was applied to the parents or caregivers on the day of the evaluation.

The incapacity of the children to adapt to the evaluating instrument as well as the presence of severe visual compromise that could negatively affect the answers to the proposed stimuli was considered as exclusion criteria.

The 10 children evaluated underwent specialized attendance including physiotherapy, speech-therapy, music therapy and pedagogic stimulation. The three eldest girls were attended at the Brazilian Association of Rett Syndrome in São Paulo (Abre-Te/SP - Associação Brasileira de Sindrome de Rett de São Paulo), and the other seven children, due to their ties to the referred-to institution, participated in this study.

Initially, the technical coordinator of Abre-Te/SP and the parents or caregivers had received explanations about the project and an informative letter about the study, which occurred after having given their consent.

This study was approved by the Research Ethics Commit- tee of Presbyterian Mackenzie University - Universidade Presbiteriana Mackenzie (process CEP/UPM 967/03/07 e CAAE 0017.0.272.000-07).

Before the evaluation, in two 30-minute weekly sessions, for 30 days, the professionals that worked with the children participating in the study presented to them the primary colors "red", "blue" and "yellow"; the shapes "square", "circle" and "triangle"; the sizes "big" and "small"; and the positions "over" and "under", naming these concepts, in a manner that assured the researcher that the children had already been exposed to the concepts being evaluated. The concepts were introduced to the children on boards supplied by the researcher, using the same model that would be presented later in the evaluation.

After this period, all of the evaluations were submitted to the Interdisciplinary Research Laboratory of the Post-graduation Program in Developmental Disorders at Universidade Presbiteriana Mackenzie, using the Tobii 1750 computerized equipment and the ClearView software (Tobii Technology, 2005), developed to evaluate and register an individual's visual scan in the face of a visual stimulus projected onto the computer screen. The equipment is capable of detecting various parameters during eye movement, such as fixation (stopped) and saccadic (moving rapidly).

The equipment is composed of a 17" TFT $1.280 \times 1.024$ pixels monitor, with two high-resolution cameras built into the lower part. To generate brilliance and reflection of the subject's eye, the equipment has built-in diodes that emit an infra-red ray (Near Infra-Red Light-Emitting Diodes - NIR-LEDs). This instrument does not offer any risk to the individual.

It is necessary to calibrate the equipment before the application of any task. To do this, the subject, while sitting in front of the monitor, must focus her look at a point on the screen that is being moved in all directions. After the equipment is calibrated, the stimuli relative to each concept were displayed on the computer screen in a manner such that the child would, with her eyes, indicate the concept that had been solicited by a simple verbal command.

The background of the displayed boards was black, in order that no stimulus other than the desired one, could influence the answers.

The images were presented by semantic group. Firstly, they were presented on a board that exhibited, inside circles, the three colors that the children had been exposed to and a different color ("green"). The child was then asked to indicate a determinate color. The color "green" was used to complete four stimuli, so that the figures would be well-distributed on the computer screen and, thereby, avoid any type of attention-calling focus distracter. The same board was presented three times, until all of the colors had been solicited. The order of the stimuli presented on the board remained unaltered to avoid a random indication that could place the child's answer into doubt. Thereafter, the board contained the three shapes to which the children had been exposed and a different one ("cross"), once again in order to complete the four stimuli on the screen. This board 
Table. Characterization of the sample.

\begin{tabular}{|c|c|c|c|c|c|c|c|c|}
\hline Subject & $\begin{array}{c}\text { Current } \\
\text { age }\end{array}$ & $\begin{array}{l}\text { Date of } \\
\text { birth }\end{array}$ & $\begin{array}{l}\text { Age of } \\
\text { clinical } \\
\text { diagnosis }\end{array}$ & $\begin{array}{l}\text { Clinical } \\
\text { stage }\end{array}$ & $\begin{array}{l}\text { Mutation } \\
\text { in } M E C P 2\end{array}$ & $\begin{array}{l}\text { Specialized } \\
\text { therapies }\end{array}$ & Schooling & $\begin{array}{c}\text { Total score on } \\
\text { Kerr et al. } \\
\text { scale }\end{array}$ \\
\hline 1 & $4 y 8 m$ & 23.01 .03 & $1 a 6 m$ & III & Negative* & $\begin{array}{l}\text { Speech therapy } \\
\text { Physiotherapy } \\
\text { Pedagogy } \\
\text { Horse therapy } \\
\text { Acupuncture }\end{array}$ & $\begin{array}{c}\text { Pre I } \\
\text { (regular school)** }^{\star *}\end{array}$ & 24 \\
\hline 2 & $6 y$ & 06.10 .01 & $3 a$ & III & Positive & $\begin{array}{c}\text { Speech therapy } \\
\text { Occupational therapy } \\
\text { Hydrotherapy }\end{array}$ & $\begin{array}{c}\text { Kindergarten } \\
\text { (regular school)** }^{\star *}\end{array}$ & 19 \\
\hline 3 & $7 y 5 m$ & 05.05 .00 & $2 a$ & III & Positive & $\begin{array}{c}\text { Speech therapy } \\
\text { Physiotherapy } \\
\text { Occupational-therapy } \\
\text { Music-therapy } \\
\text { Pedagogy }\end{array}$ & $\begin{array}{l}\text { Special room } \\
\text { (regular school)** }^{\star *}\end{array}$ & 27 \\
\hline 4 & $7 y 10 m$ & 10.12 .99 & $1 a 6 m$ & III & Positive & $\begin{array}{l}\text { Speech therapy } \\
\text { Physiotherapy } \\
\text { Occupational therapy } \\
\text { Horse therapy }\end{array}$ & Special school** & 21 \\
\hline 5 & $7 y 11 m$ & 16.11.99 & $4 a$ & III & Positive & $\begin{array}{c}\text { Speech therapy } \\
\text { Physiotherapy } \\
\text { Occupational therapy }\end{array}$ & $\begin{array}{c}\text { Pre I } \\
\text { (regular school)** }^{\star \star}\end{array}$ & 18 \\
\hline 6 & $8 y 8 m$ & 20.02 .99 & $2 a$ & III & Positive & $\begin{array}{c}\text { Speech therapy } \\
\text { Physiotherapy } \\
\text { Occupational therapy } \\
\text { Horse therapy }\end{array}$ & $\begin{array}{c}1^{\text {st }} \text { grade } \\
\text { (regular school)** }^{\star *}\end{array}$ & 17 \\
\hline 7 & $8 y 11 m$ & 26.11 .98 & $2 a 6 m$ & III & Negative* $^{*}$ & $\begin{array}{c}\text { Speech therapy } \\
\text { Physiotherapy } \\
\text { Occupational therapy }\end{array}$ & $\begin{array}{c}1^{\text {st }} \text { grade } \\
\text { (regular school)** }\end{array}$ & 21 \\
\hline $8^{* * *}$ & $10 y 8 m$ & 02.02 .97 & $2 a 8 m$ & III & Positive & $\begin{array}{l}\text { Speech therapy } \\
\text { Physiotherapy } \\
\text { Music therapy } \\
\text { Psycho-pedagogy }\end{array}$ & - & 25 \\
\hline $9 * * *$ & $12 y 9 m$ & 05.01 .95 & $5 a$ & IV & Positive & $\begin{array}{l}\text { Speech therapy } \\
\text { Physiotherapy } \\
\text { Music therapy } \\
\text { Psycho-pedagogy }\end{array}$ & - & 22 \\
\hline $10 * * *$ & $12 \mathrm{y} 10 \mathrm{~m}$ & 08.12 .94 & $1 a 9 m$ & IV & Positive & $\begin{array}{l}\text { Speech therapy } \\
\text { Physiotherapy } \\
\text { Music therapy } \\
\text { Psycho-pedagogy }\end{array}$ & - & 20 \\
\hline
\end{tabular}

*Exam will be done; **With private pedagogic stimulation; ${ }^{* * *}$ Child frequented the Reference Center AbreTe/SP - Brazilian Association of Rett Syndrome of São Paulo.

was presented three times, until all three shapes had been solicited. The boards evaluating concepts of size and position were composed of two circles. On the board relative to size, there was a larger and a smaller circle and, on the board relative to position, there was one circle above and one below.

During the evaluation, prior to presenting the first and between each stimulus, a board with a central circle was displayed so that the child would return her attention to the center of the screen, thus avoiding that she keep her eyes on the same field of the previous stimulus screen.
The evaluation included 10 verbal commands given to the children in the following order: "Look at: yellow, red, blue, triangle, square, circle, big, small, over, under".

In this study, we decided to use a permanence of three seconds for the mediator boards and four seconds for the boards that contained the solicited concepts.

The fields on the screen that contained figures-concepts were selected, and the results were analyzed based on the fixation time on the alternatives, expressed in milliseconds. These data were analyzed with the application of non-parametric 
statistical tests, constructing confidence intervals of $95 \%$ and adopting a hypothesis rejection probability of $90 \%(p \leq 0.01)$.

\section{RESULTS}

In the "colors" and "shapes" categories, the average percentages of eye fixation on each figure-concept were compared to each command given. The Friedman test demonstrated that, on the "blue" command, the tendency for eye fixation time on the color "blue" was significantly greater $(p=0.109)$; however, there was no difference observed in this time for any of the other commands relative to colors and shapes.

In turn, the Wilcoxon test revealed a significantly greater fixation time on the "non- red" stimulus when soliciting "red" ( $p=0.067)$, and on the "non-square" stimulus when requesting "square" $(p=0.066)$. Using the same statistical technique, a greater fixation time was observed on the "non-yellow" stimulus when the command was "yellow" ( $p=0.125$ ) and on the "non-circle" stimulus when soliciting "circle" ( $p=0.102)$.

To compare the average percentages of fixation time when concepts of size and spatial position were solicited and in the other groups not solicited, the Wilcoxon test identified a significantly greater fixation time on the stimulus "big" when the request was "small" $(p=0.046)$, and with the stimulus "over" when "under" ( $p=0.034)$ was requested.

In the correlation analysis between the age of the girl with RS and fixation time in all of the stimuli, Spearman's correlation coefficient validated by the correlation test indicated that: greater eye fixation time on the "blue" stimulus when "blue" was solicited was significantly correlated to a greater age $(p=0.024)$; greater eye fixation time on the "yellow" stimulus when "red" was solicited was significantly correlated to a lesser age $(p=0.082)$; and greater eye fixation time for the stimulus "triangle" to the command "triangle" was significantly correlated to a lesser age $(p=0.074)$.

The percentages of each girl's hits and misses for all of the commands were analyzed, in which the test of dual proportion equality indicated a percentage of errors significantly greater than correct answers ( $p \leq 0.01$ in all cases) for nine girls; and only one girl presenting an equal percentage of correct and incorrect responses.

\section{DISCUSSION}

Studies about cognitive aspects in individuals with RS agree that these children present severe intellectual impairment ${ }^{1,6,14}$, although the evaluation of these aspects in this population is practically rendered impossible due to the presence of great motor inability and severe verbal communication alterations ${ }^{8,14,15}$. The degree of severity in this condition is such that the constitution of a controlgroup for the study would be arbitrary.

Many studies refer to RS children using the eye as a form of communication ${ }^{8,12}$. Parents or caregivers of children with RS state that their understanding surpasses their ability to communicate, and that this is expressed through the eye ${ }^{11}$. Nonetheless, our results question these affirmations, at least in that which refers to the acquisition of basic concepts, at the same time that the conclusions of Tetzchner et al. ${ }^{12}$ are ratified: that the fixed look of these children may not necessarily signify an indication of possible cognitive capacity superior to what they seemingly have, but rather that the persistent look may constitute an indication of momentary interest and a demonstration of great social interaction.

The concepts evaluated in this study (colors, shapes, sizes and spatial positions) were selected within the patterns expected for the adequate development of children between three and six years of age.

The knowledge of colors can be acquired between two and six years of $\mathrm{age}^{16}$, and there are studies reporting that, at two years of age, children demonstrate a vast ability to name colors ${ }^{17,18}$. Through these data, studies have shown that at three years and three months of age children already know most of the colors ${ }^{19}$. It is expected that children acquire the concepts of the shapes presented with three years of age $\mathrm{e}^{20,21}$. At three or three-and-a-half years of age children already know the concepts of space and size presented ${ }^{22}$. Therefore, children with adequate development acquire the concepts used in the proposed evaluation, at a maximum, between two and six years of age.

Many studies have stressed the importance of the motor-sensory exploration of children in their world and of the things they have yet to acquire, the conceptual aspects ${ }^{20,23}$. It is known that babies at age four to six months can perceptually discriminate objects by color and shape ${ }^{24}$ and that babies at the age of 10 to 14 months can distinguish spatial representations ${ }^{25,26}$.

The RS children in our study varied in age from 4 years 8 months to 12 years 10 months, and 9 of them were 6 years old or older. During the calibration, the children being evaluated would look at the computer screen, following the circle that moved inside, indicating that they have visual perception. Considering that other similar studies using the same eye tracking equipment have demonstrated that these children possess an intentional eye ${ }^{9,10}$, our results, however, indicated that the eye of the children being evaluated did not manifest recognition of the solicited concepts, suggesting the non-acquisition of these same. The children looked, many times, at the same stimulusconcept throughout all of the different solicitations, placing their response in doubt. 
The two oldest children looked at two concepts correctly, and "blue" was commonly correct for the two. These data raise the hypothesis that, although with great lag, some RS children can learn some concepts. However, another significant correlation was that, with the increase of age, there was less eye fixation time for "triangle", when the command was to look at the "triangle". This observation contradicts the assertion that there may be more correct answers as the age of RS children advances.

Our small sample, composed of 10 children, limits the possibility of generalizing our results, but the fact that these children receive specialized attendance must be taken into account, as they are constantly stimulated and exposed to cognitive concepts, and the greater part of them are also inserted in the regular schooling process which, in and of itself, somewhat differentiates this group.

There is another methodological factor that could have possibly interfered with the results. Many researchers, concerned with evaluating the cognitive skills in RS individuals, refer to the importance of considering the amount of time these children need to respond to a stimulus ${ }^{8,1,12}$. Nonetheless, there is no report about the objective measuring of this delay in the response time. Thus, we can place into discussion whether the four-secondspan during which the concept boards were displayed to the children was insufficient, due to the difficulty of articulating eye movement and thought in conventional time.

Effective interventions presuppose strategies and techniques that stimulate skills that could be developed while, simultaneously, could please the children (in RS, for example, music is an instrument of immense pleasure). Within the possibilities of these children, the introduction and development of concepts capable of generating better life-quality and which can be used in their daily routines should be considered. Therefore, this study suggests that the pedagogic tasks now being used should be rethought, in such a way that, in fact, the passive development skills of RS children are stimulated.

The data obtained by tracking the eye of the 10 children with RS indicated that the eye does not recognize the concepts relative to the colors "red", "yellow" and "blue"; the shapes "square", "circle" and "triangle"; the sizes "big" and "small"; and the spatial positions "over" and "under".

It seems appropriate to recommend an increase of objective studies to evaluate, through visual tracking, cognitive concepts in children with RS, using new interventions and re-evaluations.

ACKNOWLEDGMENTS - The authors thank both families and patients who participated in this study, the Brazilian Association of Rett Syndrome in São Paulo (Abre-Te/SP - Associação Brasileira de Sindrome de Rett de São Paulo).

\section{REFERENCES}

1. Schwartzman JS. Síndrome de Rett. Rev Bras Psiquiatr 2003;25:110-113.

2. Schwartzman JS, Bernardino A, Nishimura A, et al. Rett syndrome in a boy with a 47, XXY karyotype confirmed by a rare mutation in the MecP2 gene. Neuropediatrics 2001;32:162-164.

3. Mercadante MT, Gaag RJV, Schwartzman JS. Transtornos invasivos do desenvolvimento não-autísticos: síndrome de Rett, transtorno desintegrativo da infância e transtornos invasivos do desenvolvimento sem outra especificação. Rev Bras Psiquiatr 2006;28(Suppl):S12-S20.

4. Amir RE, Veyver IBV, Wan M, et al. Rett syndrome is caused by mutations in X-linked MecP2, enconding methyl-CpG-binding protein 2. Nature Genetics 1999;23:185-188

5. Shahbazian MD, Young JI, Yuva-Paylor LA, et al. Mice with truncated $\mathrm{MecP} 2$ recapitulate many Rett syndrome features and display hyperacetylation of histone H3. Neuron 2002;35:243-254.

6. Pereira JLP. A síndrome de Rett. Uma introdução ao seu diagnóstico clínico, diagnóstico diferencial e ao planejamento de ações de reabilitação. Curitiba: Departamento de Educação Especial da Secretaria de Estado da Educação do Paraná, 1992.

7. American Psychiatric Association. Diagnostic and Statistical Manual of Mental Disorders, DSM-IV. Washington, DC: APA, 2002.

8. Lewis J, Wilson D. Caminhos para a aprendizagem na síndrome de Rett. (Tradução de Silvana Santos). São Paulo: Memnon, 1999.

9. Baptista PM, Mercadante MT, Macedo EC, Schwartzman JS. Cognitive performance in Rett syndrome girls: a pilot study using eyetracking technology. J Intellect Disabil Res 2006;50:662-666.

10. Amorosino C. Estudo do olhar com intenção comunicativa e vocabulário receptivo de meninas com Síndrome de Rett através do instrumento eyegaze. Dissertação (Mestrado) - Programa de Pós-graduação em Distúrbios do Desenvolvimento de Universidade Presbiteriana Mackenzie, São Paulo, 2006.

11. Hunter K. Manual del síndrome de Rett. (2002). Disponível em: <http:// www.rett.es/ eventos/manual.html>. Acesso em abril de 2007.

12. Tetzchner S, Jacobsen KH, Smith L, et al. Vision, cognition and developmental characteristics of girls and women with Rett syndrome. Dev Med Child Neurol 1996;38:212-225.

13. Kerr AM, Nomura Y, Armstrong D, et al. Guidelines for reporting clinical features in cases with MECP2 mutations. Brain Dev 2001;23:208-211.

14. Hagberg B, Hanefeld F, Percy A, Skjeldal O. An update on clinically applicable diagnostic criteria in Rett syndrome. Eur J Pediatr Neurol 2002; 6:293-297.

15. Lindberg B. Understanding Rett syndrome. Toronto: Hogrefe and Huber, 1991.

16. Roberson D, Davidoff J, Davies IR, Shapiro LR. The development of color categories in two languages: a longitudinal study. J Exp Psychol Gen 2004;133:554-571.

17. Mervis CB, Bertrand J, Pani JR. Transaction of cognitive-linguistic abilities and adult input: a case of the acquisition of color terms and color-based subordinate object categories. Br J Dev Psychol 1995;13: 285-302.

18. Shatz M, Behrend D, Gelman SA, Ebeling KS. Colour term knowledge in two year olds: evidence for early competence. J Child Lang 1996;23: 177-199.

19. Pitchford NJ, Mullen KT. Is the acquisition of basic-colour terms in young children constrained? Perception 2002;31:1349-1370.

20. Gesell A. A criança dos 0 aos 5 anos. (Tradução de Cardigos dos Reis). São Paulo: Martins Fontes, 1999.

21. Samuelson LK, Smith LB. Children's attention to rigid and deformable shape in naming and non-naming tasks. Child Dev 2000;71:1555-1570.

22. Brazelton TB, Sparrow JD. 3 a 6 anos. Momentos decisivos do desenvolvimento infantil. (Tradução de Cristina Monteiro). Porto Alegre: Artmed, 2003.

23. Belini AEG, Fernandes FDM. Olhar de bebês em desenvolvimento típico: correlações longitudinais encontradas. Rev Soc Bras Fonoaudiol 2007;12:165-173

24. Franklin A, Davies IRL. New evidence for infant colour categories. Brit J Dev Psychol 2004;22:349-377.

25. Quinn PC, Adams A, Kennedy E, Shettler L, Wasnik A. Development of an abstract category representation for the spacial relation between in 6 to 10 month old infants. Dev. Psychol 2003;39:151-163.

26. Casasola M. When less is more: how infants learn to form an abstract categorical representation of support. Child Dev 2005;76:279-290. 